can Academy of Neurology algorithm for HIV-1-associated cognitive/motor disorder. Neurology 1996;47:1247-1253.

6. Lawton MP, Brody EM. Assessment of older people: selfmaintaining and instrumental activities of daily living. Gerontologist 1969;9:179-186.

7. Katz S, Ford A, Moskowitz R. Studies of illness in the aged: the index of ADL. JAMA 1963;183:914-919.

8. Stewart AL, Ware JE. Measuring function and well-being: the medical outcomes study approach. Durham, NC: Duke University Press, 1993.

9. Karnofsky DA, Abelman WH, Craver LF, et al. The use of nitrogen mustards in the palliative treatment of carcinoma. Cancer 1948;1:634-656.

10. Erkinjuntti T, Ostbye T, Steenhuis R, et al. The effect of different diagnostic criteria on the prevalence of dementia. N Engl J Med 1997;337:1667-1674.

\title{
Neuro/mages
}
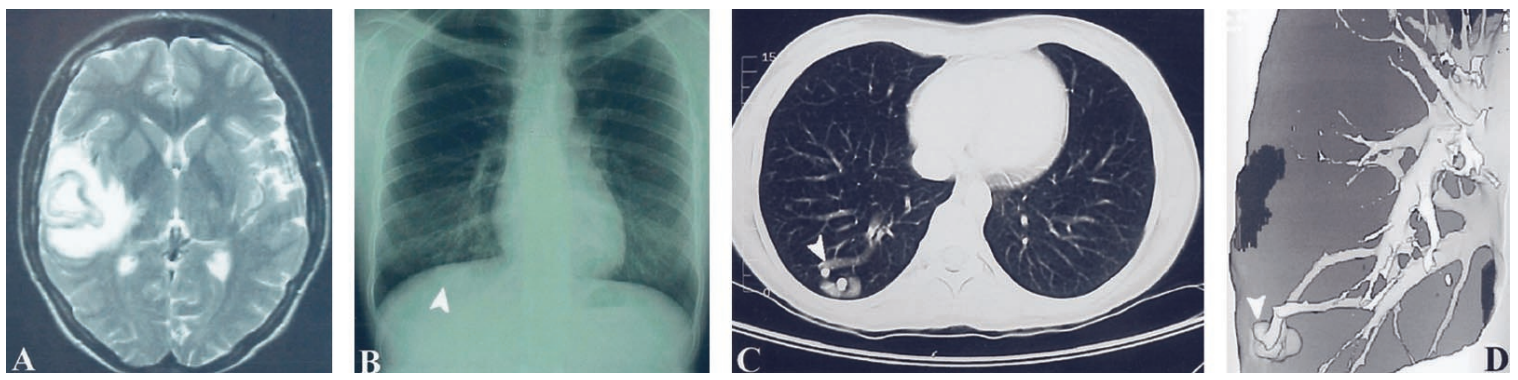

Figure. (A) Axial T2-weighted MRI-right temporal brain abscess with surrounding edema; (B) chest x-ray shows mass at right base; (C) axial chest $C T$ - enhancing vascular mass at right base; (D) three-dimensional chest CT reconstruction demonstrates a right pulmonary arteriovenous fistula.

\section{Pulmonary arteriovenous fistula and brain abscess}

David C. Preston, MD, Barbara E. Shapiro, $M D, P h D$ Cleveland, $\mathrm{OH}$

A 23-year-old woman presented with 3 days of headache followed by complex partial seizures. Stereotactic aspiration of a large right temporal mass revealed purulent material with Gram-positive cocci (Streptococcus millieri). Chest radiograph and $\mathrm{CT}$ scan demonstrated a pulmonary arteriovenous fistula (PAVF). PAVF are low resistance, abnormal connections between a pulmonary artery and distended vein. They may occur as an isolated entity or associated with hereditary hemorrhagic telangiectasia (Osler Weber Rendu syndrome). PAVF often present with neurologic symptoms, usually stroke, TIA, or brain abscess from the right to left shunt that bypasses the normal filtering action of the lungs.

1. Moussouttas M, Fayad P, Rosenblatt M, et al. Pulmonary arteriovenous malformations: cerebral ischemia and neurologic manifestations. Neurology 2000;55:959-964.

2. Swanson KL, Prakash UB, Stanson AW. Pulmonary arteriovenous fistulas: Mayo Clinic experience, 1982-1997. Mayo Clin Proc 1999;74:671680 . 


\title{
Neurology
}

\author{
Pulmonary arteriovenous fistula and brain abscess \\ David C. Preston and Barbara E. Shapiro \\ Neurology 2001;56;418 \\ DOI 10.1212/WNL.56.3.418
}

This information is current as of February 13, 2001

\section{Updated Information \&} Services

References

Permissions \& Licensing

Reprints including high resolution figures, can be found at: http://n.neurology.org/content/56/3/418.full

This article cites 2 articles, 1 of which you can access for free at: http://n.neurology.org/content/56/3/418.full\#ref-list-1

Information about reproducing this article in parts (figures,tables) or in its entirety can be found online at:

http://www.neurology.org/about/about_the_journal\#permissions

Information about ordering reprints can be found online: http://n.neurology.org/subscribers/advertise

Neurology ${ }^{\circledR}$ is the official journal of the American Academy of Neurology. Published continuously since 1951, it is now a weekly with 48 issues per year. Copyright. All rights reserved. Print ISSN: 0028-3878. Online ISSN: 1526-632X.

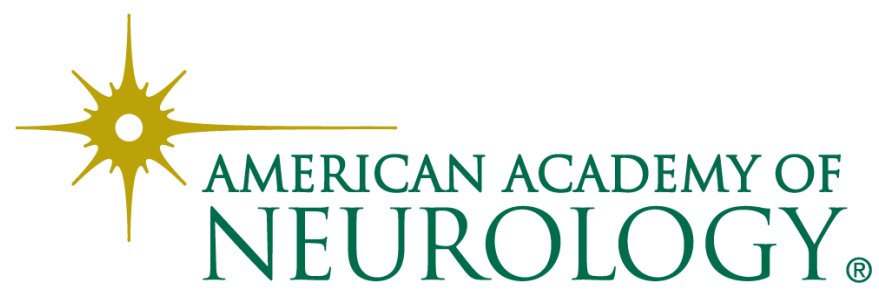

